\title{
Changes in runoff in two neighbouring catchments in the Bohemian Forest related to climate and land cover changes
}

\author{
Jana Bernsteinová $^{1 *}$, Claus Bässler ${ }^{3}$, Lothar Zimmermann ${ }^{2}$, Jakub Langhammer ${ }^{1}$, Burkhard Beudert ${ }^{3}$ \\ ${ }^{1}$ Department of Physical Geography and Geoecology, Faculty of Natural Sciences, Charles University Prague, Albertov 6, 120 00, Prague, \\ Czech Republic. \\ ${ }^{2}$ Bavarian State Institute of Forestry, Hans-Carl-von-Carlowitz-Platz, D-85354 Freising, Germany. \\ ${ }^{3}$ Bavarian Forest National Park, Freyunger Straße 2, D-94481 Grafenau, Germany. \\ ${ }^{*}$ Corresponding author. Tel.: +420 739345 206. Fax:+420 271736 912. E-mail: jana.kaiglova@gmail.com
}

\begin{abstract}
There is public concern that large-scale disturbances to forest cover caused by insects and storm winds in the Bohemian Forest could intensify high water flows and enhance the expected flooding risks predicted in current regional climate change scenarios. We analysed stream discharge in Upper Vydra and Große Ohe, neighbouring catchments in the Bohemian Forest, the largest contiguous forested area in Central Europe. Upper Vydra, in the Šumava National Park, and Große Ohe (including the Upper Große Ohe headwater catchment in the Bavarian Forest National Park) are similar in size, but differ in land use cover and the extent of disturbed Norway spruce stands. Publicly available runoff and meteorological data (1978-2011) were examined using non-parametric trend and breakpoint analysis. Together with mapped vegetation cover changes, the results were used to address the following questions: 1) are there significant changes in the hydrological cycle and, if so, do these changes relate to 2) the extent and expansion of disturbance in forests stands and/or 3) altered precipitation dynamics and thermal conditions?

We found no marked overall change in annual runoff or in annual or seasonal precipitation, but a significant increase in high flows in March. This overall trend related to the marked warming in late winter and early spring (+ 4 K in April, $\mathrm{p}<0.01$ ), irrespective of altitude and slope position. It significantly shifted the end of the snow cover period by more than three weeks to the beginning/middle of April depending on altitude, and intensified snow melt.

In the Upper Große Ohe catchment, a significant decrease in catchment balance, the difference between the long term precipitation and runoff $(-72 \mathrm{~mm}, 11 \%)$ was found when the loss of tree cover reached $30 \%$ of catchment area. Diminished evapotranspiration losses from severely disturbed stands increased groundwater recharge during summer and caused a significant rise in low flows in autumn.

However, observed increases in late winter high flows were due to warming only. They could be further intensified by the increasing winter precipitation predicted under present climate change scenarios, and would therefore increase the risk of flooding at lower elevations.
\end{abstract}

Keywords: Runoff; Climate change; Forest disturbance.

\section{INTRODUCTION}

There is only a moderate degree of certainty that precipitation has increased in the mid-latitudes of the northern hemisphere through human influence (IPCC 2013). The observed increase is attributed to rising air temperature, which intensifies hydrological cycling, leading, in turn, to altered atmospheric circulation and a poleward shift in storm tracks (Marvel and Bonfils, 2013). However, in contrast to model results, satellite data show that, in recent decades (1987-2010), precipitation has decreased in all seasons in moist regions in the midlatitudes of the northern hemisphere (Polson et al., 2013). Changes in the hydrological cycle at the earth's surface are also directly related to warming, which, depending on the season in which warming has occurred, alters the solid-liquid partitioning of precipitation, snow cover dynamics and evapotranspiration rate (Hidalgo et al., 2009).

In forested landscapes, the indirect effects of climate change are of particular importance. Increased temperatures can reduce tree vitality even when no decrease in precipitation occurs (Adams et al., 2009) and, at the same time, accelerate the growth and size of insect populations (Raffa et al., 2008; Seidl et al., 2011), and thereby cause tree die-off over large areas (Allen et al., 2010). After tree die-off, evapotranspiration from overstorey vegetation declines, while energy and water flow to the understory and on the soil surface increases (Adams et al., 2012). Consequently, water fluxes into and through the soil are altered, resulting in changes in the generation of discharge (i.e. contributions of groundwater and subsurface flows to runoff) and in the runoff yield itself when catchment area affected is large (Beudert et al., 2007).

In the Bohemian massif, which is covered predominantly by Norway spruce forests (Picea abies (L.) Karst.), air temperature has increased over the last century (Bässler, 2008; Kliment and Matoušková, 2008), resulting in a significant shift in insect habitats, in particular, towards higher elevations (Bässler et al., 2010). On the European scale (Seidl et al., 2011), the outbreak of the host-specific spruce bark beetle (Ips typographus L.), which has affected mature Norway spruce forests over large areas of the Bavarian Forest and Šumava National Park (Hais et al., 2009), was probably the most drastic outcome of accelerated warming and frequent storms in the early 1990s.

Only few studies exist which focus on regional changes in runoff and discharge dynamics induced by Ips typographus. Both Beudert et al. (2007) and Klöcking et al. (2005) found increased runoff coefficients and greater subsurface flows in two headwaters of the Upper Große Ohe catchment in the Bavarian Forest National Park. However, their data covered the first five to seven years after the first massive bark beetle outbreak only. In Šumava National Park, Kliment and Matoušková 
(2008) found only small changes in runoff in two comparable streams between 1962 and 2002, while Buchtele et al. (2006) found evidence of runoff changes caused by changes in vegetation cover caused, in turn, by bark beetle and storms.

In this study, publicly available meteorological and runoff data (1978-2011) for two similar-sized neighbouring catchments (Upper Vydra, Große Ohe) and one nested headwater catchment (Upper Große Ohe) in the Bohemian Forest were analysed. Using time series analysis, we 1) tested the overall and seasonal trends in catchment hydrology, and distinguished the influence of 2a) climate change as a cross-scale factor from $2 b)$ forest disturbance acting on a catchment scale.

\section{MATERIALS AND METHODS Catchments characteristics}

The study area comprised the Große Ohe (GO; gauging station Schönberg, Germany) and Upper Vydra (UV; gauging station Modrava, Czech Republic) catchments, which drain the southern and northern slopes of the Bohemian massif, respectively (Fig. 1, Table 1).

The mountain range represents a hydrological divide between the North and Black seas as well as a meteorological divide between continental high pressure and Atlantic low pressure zones. The regional climate is characterized by high precipitation with a high percentage of snow. On the summits, total annual precipitation amounts to $2500 \mathrm{~mm} \mathrm{yr}^{-1}$ (Klöcking et al., 2005), divided almost equally between summer and winter. In the nested Upper Große Ohe catchment (UGO; gauging station Taferlruck, Fig. 1, Table 1), the mean annual precipitation lapse rate is $64 \mathrm{~mm}$ per $100 \mathrm{~m}$ elevation (Klöcking et al., 2005), but amounts to $100 \mathrm{~mm}$ per $100 \mathrm{~m}$ elevation on the south-westerly slopes (Beudert and Breit, 2004). At the Waldhäuser weather station near UGO (940 m a.s.l., Fig. 1), the mean annual air temperature over the study period was $6.0^{\circ} \mathrm{C}$ ( \pm 0.7$)$. At the Churáňov weather station near UV (1118 m a.s.l., Fig. 1), the mean annual air temperature was $4.7^{\circ} \mathrm{C}( \pm 0.8)$. Mean temperatures of the winter half-year were $-1.1^{\circ} \mathrm{C}( \pm 1.1)$ at Churáňov and $0.3^{\circ} \mathrm{C}( \pm 1.0)$ at Waldhäuser. Assuming a mean density of $0.1 \mathrm{~g} \mathrm{~cm}^{3}$ of freshly fallen snow at Waldhäuser (mean depth of $413 \pm 117 \mathrm{~cm}$ ), then, in water equivalent terms, snow accounted for $58 \%$ of total precipitation in the winter half-year $(733 \pm 160 \mathrm{~mm})$. Similar snowfall conditions can be expected at Churáňov and in UV, whereas, in GO, snowfall, and thus snow water storage, is of minor importance due to its lower elevation. The bedrock in both catchments consists of granite and gneiss, overlain by quaternary sediments, mostly periglacial solifluction deposits and fluviatile sediments (Table 1). Quaternary sediments cover only $17 \%$ of bedrock in UV, but $50 \%$ in GO.

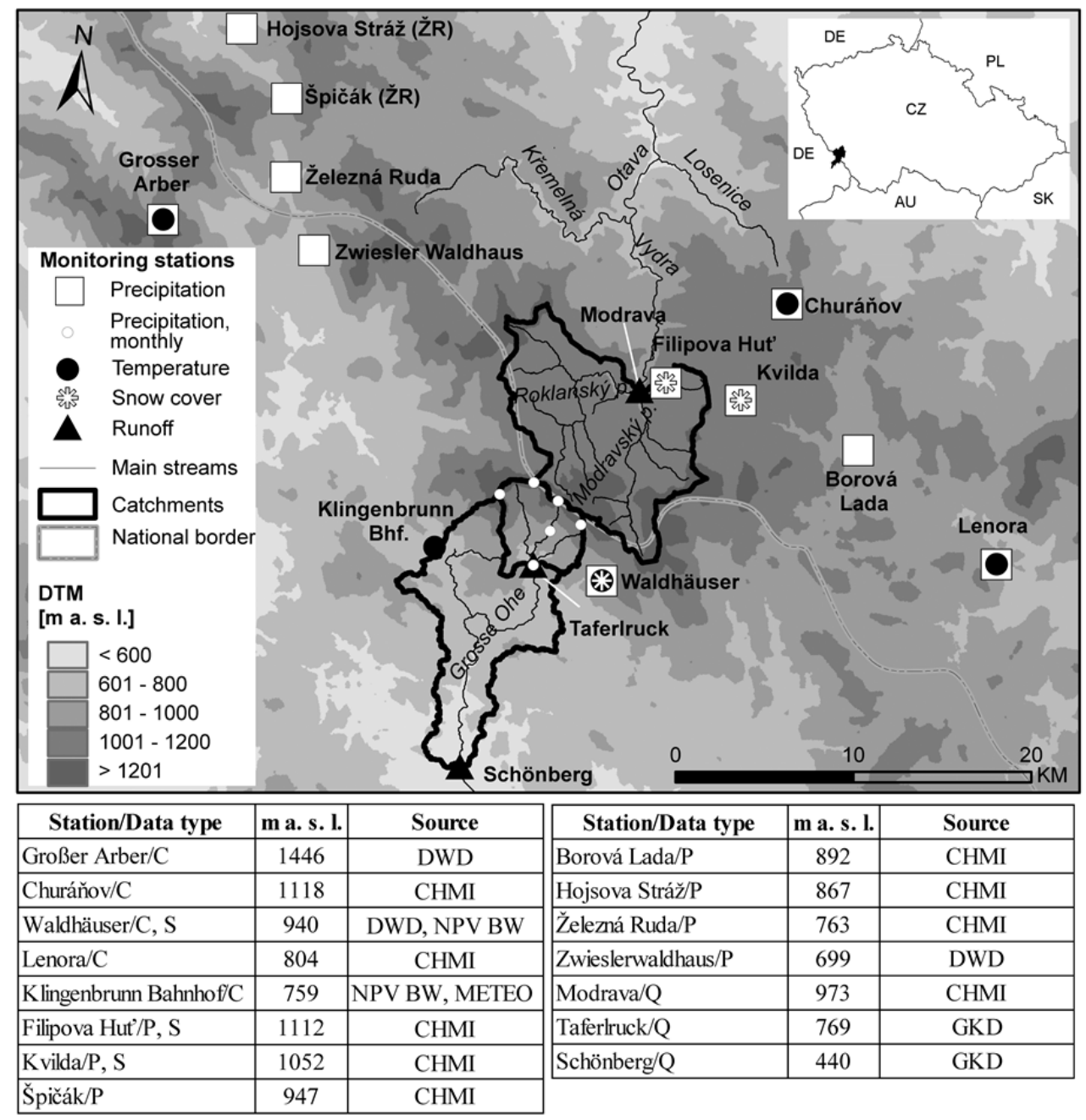

Fig. 1. Digital terrain model of the study area with Große Ohe (GO), Upper Große Ohe(UGO) and Upper Vydra (UV) catchments, weather and gauging stations. Abbreviations: C (Precipitation, air temperature), P (Precipitation), Q (Discharge), S (Snow cover). See text for abbreviations of data sources. Note that solid white circles indicate precipitation stations used to calculate UGO catchment precipitation. 
Table 1. Basic catchment characteristics. Runoff statistics are given for the 1978-2011 period; status of land cover in brackets.

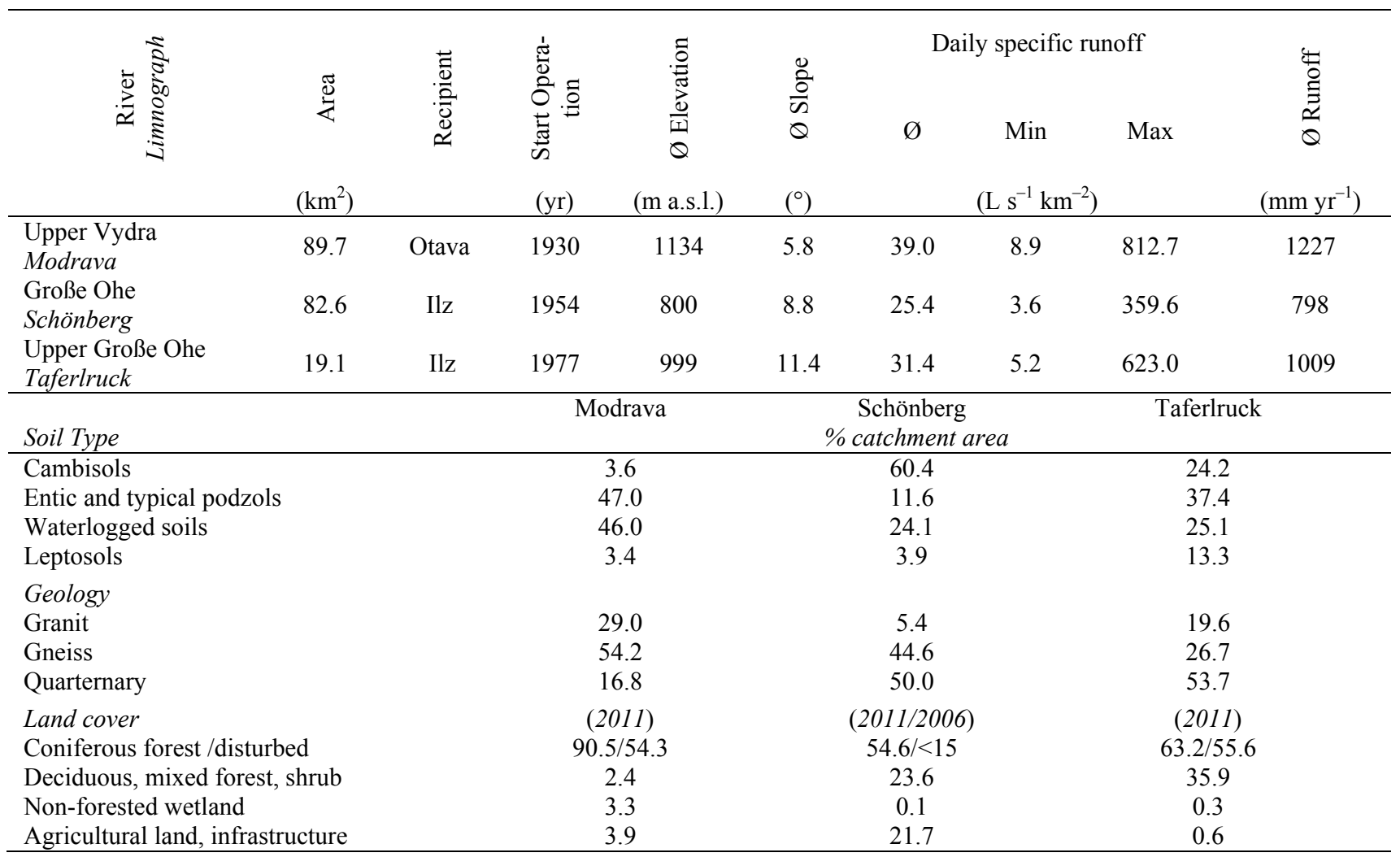

Although the catchment areas of $83 \mathrm{~km}^{2}$ (GO) and $90 \mathrm{~km}^{2}$ (UV) are similar, they differ in three main aspects; (1) percentage area coverage of soil types, (2) dominant land use, and (3) the extent of die-off caused by the spruce bark beetle Ips typographus and windfall.

(1) Compared to UV, GO has a lower mean elevation of $800 \mathrm{~m}$ a.s.l., but a much larger altitudinal gradient $(1013 \mathrm{~m})$ and a steeper mean slope $\left(8.8^{\circ}\right)$. The nested UGO $\left(19 \mathrm{~km}^{2}\right)$ has a mean elevation of $999 \mathrm{~m}$ a.s.l. and the steepest mean slope $\left(11.4^{\circ}\right)$ of the three catchment areas studied. UV spans the top of a gneiss/granite plateau and has a mean elevation of $1134 \mathrm{~m}$ a.s.l. The altitudinal gradient is $480 \mathrm{~m}$ and the mean slope is $5.8^{\circ}$. Consequently, in UV, the percentage area covered by waterlogged soils (46\%) and entic (podsolic cambisols) and developed podsols $(47 \%)$ is equivalent. In contrast, waterlogged soils cover $25 \%$ of GO and UGO. In these areas, podzols comprise $37 \%$ and $12 \%$ and cambisols, $24 \%$ and $60 \%$ of the area, respectively.

(2) UV is part of the Šmava National Park (NP Š) and the land cover is dominated by Norway spruce $(91 \%)$ forests, while UGO is part of the Bavarian Forest National Park (NP BW) and is covered by deciduous and mixed stands $(36 \%$, mostly European beech) and coniferous forest stands (63\%, mostly Norway spruce). In GO agricultural land comprised $22 \%$ of the land cover.

(3) Bark beetle outbreak and windfall has caused the greatest changes in land cover in UV and UGO. By 2011, tree die-off affected $55 \%$ and $56 \%$ of these catchments, respectively. In contrast, disturbances were of minor importance in GO $(<15 \%)$ due to different vegetation cover, land use and management.

The intra-annual runoff distribution was very similar in all catchments (Fig. 2, left) and followed a pluvial to pluvio-nival regime with maximum runoff yields in the meteorological spring. This period contributed $38 \%, 41 \%$ and $44 \%$ to annual runoff in GO, UV and UGO respectively. In UV and UGO, elevated spring runoff occurred during the whole period while in GO, it occurred in March and April only. In UV and UGO, small contributions of less than $8 \%$ runoff per month were recorded from June to February, without any clear attribution to season or month. In contrast, GO showed medium runoff contributions from November to February.

Flow duration relationships revealed the same curvature in UV and GO (Fig. 2, right) but differed consistently in size. Mean low flow in UV $\left(1.1 \pm 0.2 \mathrm{~mm} \mathrm{~d}^{-1}\right)$ almost doubled compared to GO $\left(0.6 \mathrm{~mm} \mathrm{~d}^{-1} \pm 0.2\right)$, while the difference in mean high flow was less pronounced $\left(21.5 \mathrm{~mm} \mathrm{~d}^{-1}\right.$ versus $\left.9.3 \mathrm{~mm}\right)$. The nested UGO equaled GO in low flows but markedly exceeded UV in high flows $\left(30.1 \mathrm{~mm} \mathrm{~d}^{-1} \pm 12.3 \mathrm{~mm}\right)$.

\section{Data sources}

Precipitation stations (P, Figure 1) in Šumava (run by the Czech Hydrometeorological Institute, CHMI) are located between 763 and $1118 \mathrm{~m}$ a.s.l., while Bavarian stations (run by the German Weather Service, DWD, and NP BW) span an altitudinal range from $699 \mathrm{~m}$ to $1446 \mathrm{~m}$ a.s.l. (Großer Arber). These weather stations, most of which are outside the study area, were selected on the basis of their proximity, similar elevation, duration of weather data records (1978-2011) and data reliability. In UGO, records of monthly total precipitation (operated by Bavarian State Institute of Forestry, LWF) were used to calculate mean catchment precipitation (Klöcking et al., 2005). The recording locations spanned an altitudinal range of $770 \mathrm{~m}$ to $1360 \mathrm{~m}$ a.s.l. Climate stations (C; Fig. 1) measuring temperature and precipitation (including snow cover) ranged in altitude from 759 to $1446 \mathrm{~m}$ a.s.l. and represented all positions along the slope from the valley bottom to the summit. Discharge data were obtained from the Czech Hydrometeorological Institute (CHMI) and the Bavarian Hydrological Service (GKD). 

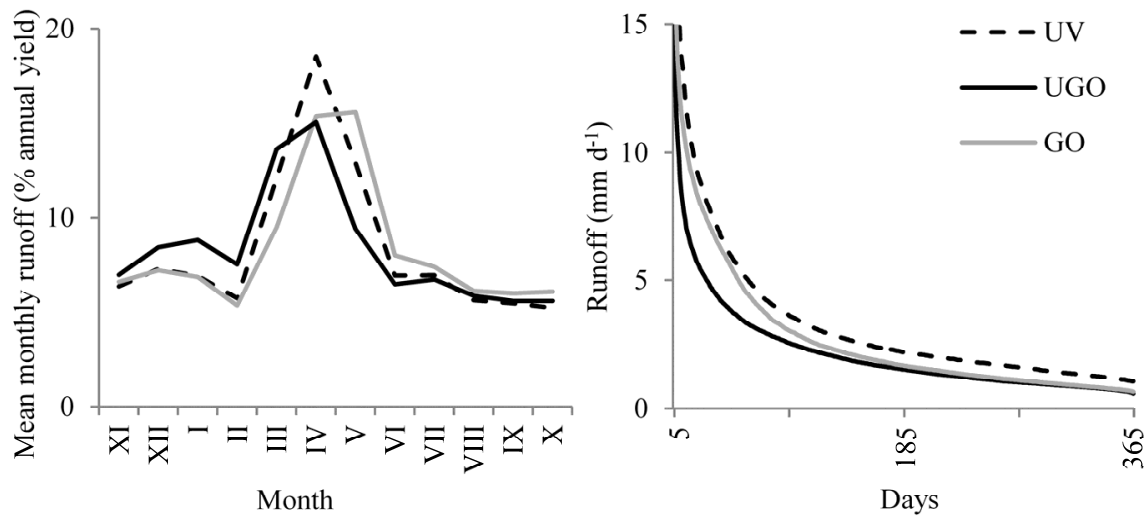

Fig.2. Mean intra-annual runoff distribution (left) and mean duration curves (right) for the study catchments. Note that runoff exceeding $15 \mathrm{~mm} \mathrm{~d}^{-1}$ was excluded.

Data for catchment characteristics were derived from the DMR $4 \mathrm{G}$, grid size $5 \times 5 \mathrm{~m}\left(4^{\text {th }}\right.$ Generation Digital Terrain Model from Czech Office for Surveying, Mapping and Cadastre ČÚZK), Corine Land Cover (CLC) 2006 (European Environmental Agency), ČGS (Czech Geological Survey) and BIS Bayern (Bavarian State Service). Vegetation cover change maps were constructed from spatial data obtained from both the Czech and Bavarian park services. The datasets were analysed by Arc Editor 10.1 Spatial Analyst Tools package (ESRI).

\section{Data processing and statistics}

Daily data from official weather services were adopted without modification. Reliability of discharge data was tested using double mass curve analysis and Pettitt test (Project team ECA\&D, 2013) using R 3.1.3 (www.r-project.org). None of the tests revealed significant $(\mathrm{p} \leq 0.05)$ inhomogeneity.

Seasonal (monthly to annual) percentiles (P10-P90) of $10 \%-90 \%$ (low to high flow) were calculated from daily means for every year. The percentiles reflect combined effects of meteorological variations and other causal factors. In a second approach, seasonal runoff percentiles were divided by the respective seasonal median runoff (Archer and Newson, 2002) to derive relative percentiles. The aim of obtaining multiples of median runoff was to decouple runoff from the annual variation in precipitation to determine whether discharge variability over time was due to warming or changes in vegetation cover. For example, an increase in relative low flows may simply be due to decreasing runoff and unaltered low flows, or due to increasing low flows while seasonal runoff remains constant.

Trend statistics (see below) were performed for monthly, seasonal and annual runoff yields, and for percentiles and relative percentiles to detect changes in runoff and in absolute, and relative low (P10-P30) and relative high (P70-P90) flows. The total change over the study period $\left(\mathrm{mm}=\mathrm{mm} \mathrm{yr}^{-1} 33 \mathrm{yr}\right)$ was added when rates of change were small but of hydrological significance.

An a priori test for autocorrelation ("acf" package) using $\mathrm{R}$ 3.1.3 (www.r-project.org) resulted in a weak correlation at a lag of 7 in very few data sets only. The non-parametric MannKendall test (Hirsch et al., 1982) was applied to all meteorological and hydrological data sets to detect monotonic trends. SEN's nonparametric method (Gilbert, 1987) was used to calculate the slope of linear trends. Both tests are combined in the MAKESENS EXCEL-template (Määttä et al., 2002).

The annual runoff coefficient was calculated by relating runoff to catchment precipitation $(\%)$ to obtain a runoff measure which accounts for variability in climate. The "segmented regression with breakpoint" procedure (SegReg, Oosterbaan, 1994, Snedecor and Cochran, 1980, www.waterlog.info) was used to detect changes in the annual runoff coefficient over time. The breakpoint was verified with the Mann-Whitney-Pettitt test using ANKLIM (Stepánek, 2008) and the standard normal homogeneity, Pettitt and Buishand range test functions (Project team ECA\&D, 2013) using R 3.1.3 (www.r-project.org). SegReg partitions an independent variable (time) into two intervals and calculates separate line segments for each interval. The two segments may contain horizontal lines as well as upward and downward sloping line segments to either side of the breakpoint. Differences in mean values before and after the breakpoint were tested using a two sample t-test (Wessa, 2014).

\section{RESULTS \\ Trends in runoff frequency, magnitude and seasonal distribution}

Over the study period from 1978 to 2011 Annual runoff yields changed by $+2.2 \mathrm{~mm} \mathrm{yr}^{-1}(+8 \%)$ in UGO and -1.5 $\mathrm{mm} \mathrm{yr}^{-1}$ in GO $(-8 \%)$. These changes were caused by significant quantitative changes in runoff in March in UGO $\left(+2.2 \mathrm{~mm} \mathrm{yr}^{-1},+118 \%\right)$ and May in GO $\left(-1.5 \mathrm{~mm} \mathrm{yr}^{-1},-46 \%\right)$. Runoff changes in UV were very small $\left(-1.0 \mathrm{~mm} \mathrm{yr}^{-1},-3 \%\right)$ arising from a decrease in summer (May) and increase in winter (March and April) of similar size.

Neither in UGO nor in GO was there evidence of a significant trend in annual runoff percentiles (Fig. 3). In UV, annual values for low (P10) to medium flow (P60) decreased by 0.4 to $0.5 \mathrm{~mm}$ from 1978 to 2011 . Low flows demonstrated the strongest statistical $(\mathrm{p} \leq 0.01)$ and hydrological significance $(-27 \%$, Fig. 3). The increase in high discharges partly compensated for the decrease in low discharges, although this was not significant due to high variability. An increase in high flow in the hydrological winter half-year was found in all catchments, but was only significant in UV (Fig. 3). This increase occurred mainly in March, exhibiting an total increase in high flow of 3.9, 3.6 and $6.1 \mathrm{~mm}$ in UV, GO and UGO respectively, whereby, in UV, an increase in high flow of $3.9 \mathrm{~mm}$ was also recorded in April. The increase in late winter discharge was followed by a decrease in discharge in the summer season, which was particularly marked in May, with slightly significant changes at least over the whole range of discharge percentiles in both UGO and GO and likewise in UV. 


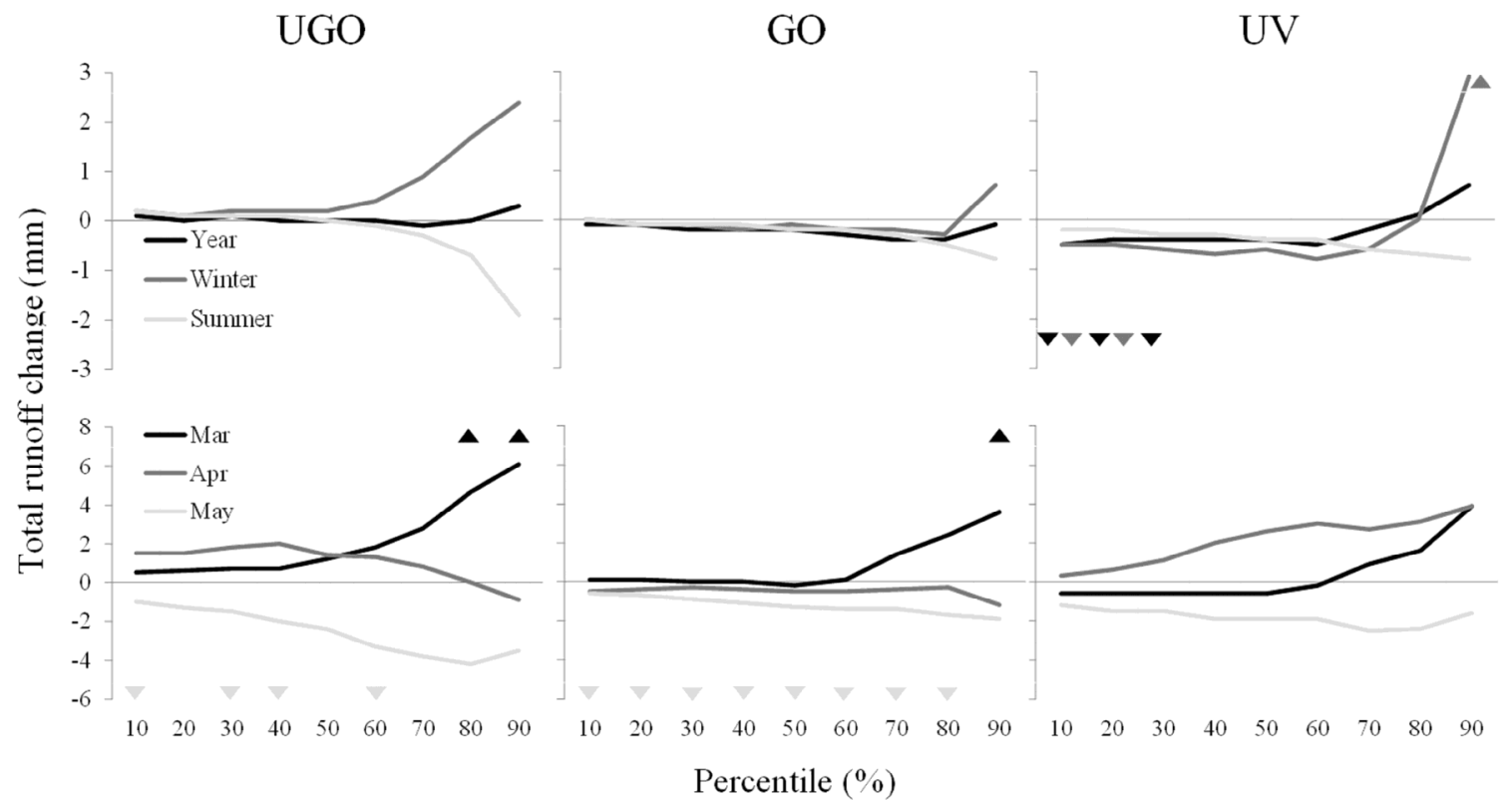

Fig. 3. Total change in runoff percentiles $\mathrm{P} 10-\mathrm{P} 90$ in GO, UGO and UV. Upward and downward facing arrows mark significant trends $(\mathrm{p}<0.05)$ in the respective period. Top: Hydrological years and half years. Bottom: months of meteorological spring.

Trend analysis of relative annual runoff percentiles (multiples of median) revealed a diverging tendency towards higher variability in UV (Fig. 4). The winter half-year was characterized by statistically significant increases in P80 and P90 in UV. In March, relative high flows (P60-P90) increased in all catchments; the higher the percentile, the larger the slope. In April, relative low flows (P10-P30) decreased significantly in UV, whereas relative high flows (P60-P90) decreased significantly in UGO.

In May, relative low flows increased at all stations; in UV relative high flows increased as well. Significant decreases in relative high flows in the hydrological summer half-year were found in UGO only.

Overall, reduced variability in discharge in UGO resulted from decreasing relative high flows and increasing relative low flows during summer. Similar, though mostly insignificant, changes were also observed in GO. In contrast, in UV a diverging pattern of rising high flows in winter with no change in summer was found.

\section{Trends in precipitation}

Annual precipitation increased $(\mathrm{p}>0.05)$ at all Bohemian stations with the highest increments at Kvilda $\left(4.8 \mathrm{~mm} \mathrm{yr}^{-1}\right)$ and Špičák (6.6 $\left.\mathrm{mm} \mathrm{yr}^{-1}\right)$. At Bavarian stations, annual precipitation decreased slightly or remained unchanged (Table 2). At most stations, these changes were the net result of increasing summer precipitation and decreasing winter precipitation. Precipitation decreased in the first half of the winter and increased in the second half. The resulting decrease in winter precipitation was insignificant at most stations. Yet, at all stations, an increase in summer precipitation was found, which resulted from increases in the first half of the summer and no change between August and October. Overall, changes in precipitation yields at Bavarian and Bohemian stations were similar. Yet, the higher increases in summer and equal decreases in winter generated small increases in annual precipitation at Bohemian stations, whereas at Bavarian stations, including UGO (1980-2011), small decreases prevailed. The direction in precipitation trends was independent of elevation and relative slope position (valley, slope, summit), while their magnitude was influenced by sitespecific conditions. Further, precipitation intensities examined at Churáňov and Waldhäuser did not change significantly.

\section{Trends in air temperature}

Annual mean temperatures increased significantly, ranging from 0.4 (Lenora) to $0.5 \mathrm{~K} \mathrm{yr}^{-1}$ (Waldhäuser and Churáňov); the rates of increase were similar in winter and summer halfyears. Mean air temperature did not change in March, September, October or December at any station, whereas moderate (insignificant) increases of up to $0.07 \mathrm{~K} \mathrm{yr}^{-1}$ occurred in January, February and November (Fig. 5, left). From May to July (August), significant increasing trends were found at all stations, in most cases ranging from 0.04 to $0.08 \mathrm{~K} \mathrm{yr}^{-1}$. Warming was greatest in April, with highly significant trends between 0.10 and $0.12 \mathrm{~K} \mathrm{yr}^{-1}$. Thus mean April temperatures increased by at least $3.5 \mathrm{~K}$ over 33 years at all sites.

By including the stations Klingenbrunn Bhf. (759 m a.s.l) and Großer Arber (1446 m a.s.1.) in the Bavarian Forest, the extended temperature database (1983-2011) covered the whole altitudinal range of the study area. Plotting temperature trends against altitude (Fig. 5, right) clearly showed that February and April trends (significant) as well as June trends (significant) were independent of altitude. Moreover, relative slope position did not influence temperature trends.

\section{Land cover changes}

Bark beetle outbreaks and tree die-off occurred in two major waves in UGO (Fig. 6). The first wave (1994-2000) seriously affected Norway spruce stands over $36 \%$ of the area. During the second wave (2005-2009), die-off in another $16 \%$ of the catchment area resulted in a loss of mature Norway spruce stands. A total $58 \%$ of the mature Norway spruce stands in the catchment was lost over the period 1989 to 2011. 
Table 2. Precipitation trends $\left(\mathrm{mm} \mathrm{yr}^{-1}\right)$ at Bohemian and Bavarian stations (1978-2011) and in UGO (1980-2011). Roman numerals indicate calendar months; italics: $\mathrm{p} \leq 0.05$.

\begin{tabular}{lcccccccc}
\hline Station & $\begin{array}{c}\text { Elevation } \\
\text { m a.s.1. }\end{array}$ & $\begin{array}{c}\text { Hydrol. } \\
\text { year }\end{array}$ & XI-I & II-IV & & Winter & & \multicolumn{2}{c}{ Summer } \\
\hline Zwieslerwaldhaus & 699 & -1.7 & -3.2 & 1.7 & -1.8 & 0.4 & -0.4 & 0.3 \\
Waldhäuser & 940 & -3.3 & -5.9 & 0.0 & -6.0 & 3.1 & -1.2 & 2.0 \\
Upper Große Ohe & 999 & 0.7 & -5.6 & 2.0 & -4.9 & 2.4 & -0.1 & 1.1 \\
Churáňov & 1118 & 0.2 & -2.5 & 1.6 & -1.6 & 1.4 & -0.1 & 1.8 \\
Kvilda & 1052 & 4.8 & -2.2 & 2.6 & -1.1 & 2.8 & 0.9 & 4.4 \\
Žel. Ruda, Špičák & 947 & 6.6 & -0.4 & 3.0 & 1.6 & 3.9 & 1.1 & 5.4 \\
Borová Lada & 892 & 2.4 & -2.4 & 2.0 & -1.4 & 2.6 & -0.9 & 1.8 \\
Žel. Ruda, Hojsova Str. & 867 & 0.1 & -2.5 & 0.8 & -2.2 & 1.3 & -0.1 & 2.7 \\
Lenora & 804 & 0.8 & -2.6 & 0.7 & -1.7 & 1.6 & 0.0 & 2.0 \\
& & & & & & & & \\
Decreasing trend (\%) & & 25 & 100 & 13 & 88 & 0 & 75 & 0 \\
Increasing trend (\%) & & 75 & 0 & 88 & 13 & 100 & 25 & 100 \\
\hline
\end{tabular}

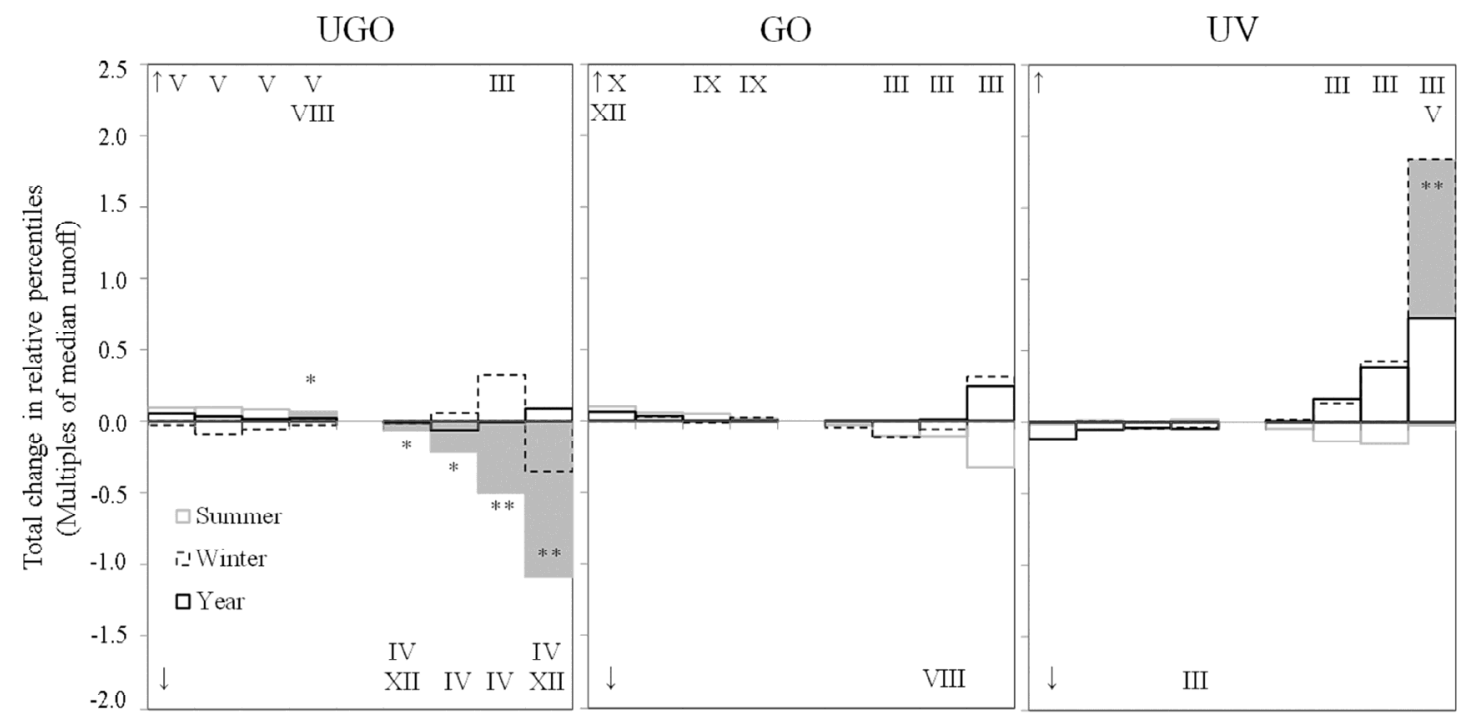

Fig. 4. Total change in relative runoff percentiles (P10-P90) over the whole study period represented as multiples of the median of the respective season: bars indicate hydrological year and seasons, grey fills statistical significance. $*: p \leq 0.05, * *: p \leq 0.01$. Roman numerals at the top (increasing) and bottom (decreasing) of the figure frame designate individual months with significant trends $(\mathrm{p} \leq 0.05)$ in the respective percentile.
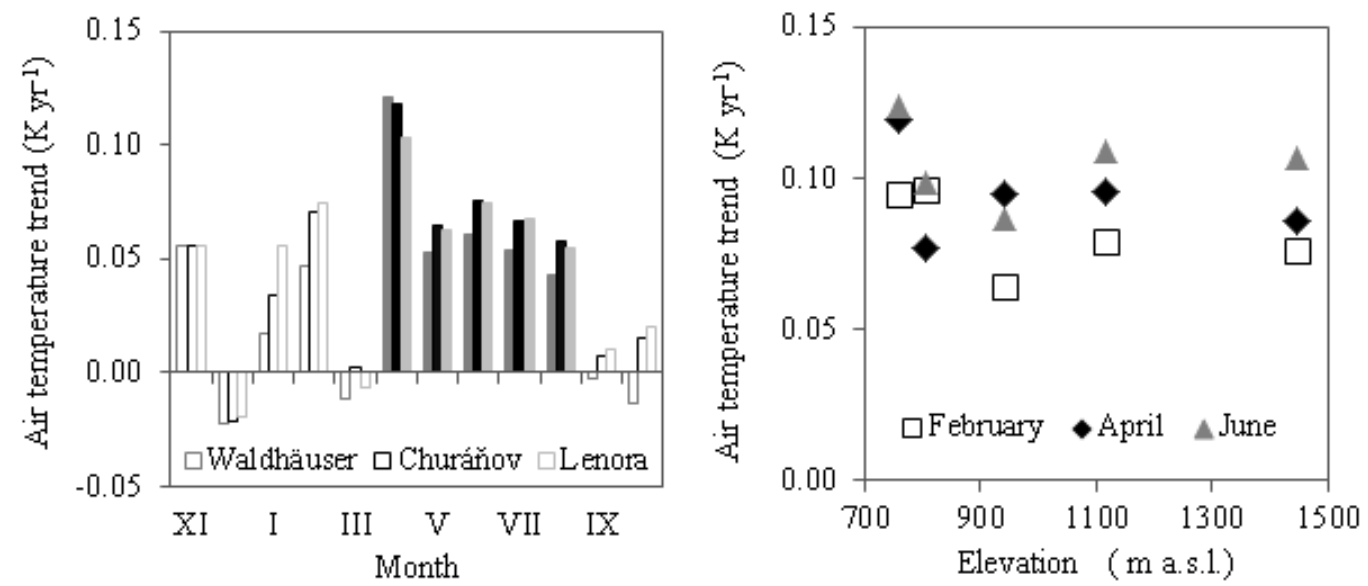

Fig. 5. Left: Trends in monthly mean air temperature (1978-2011) at Waldhäuser, Churáňov and Lenora station. Right: Trends in February, April and June mean air temperature by altitude (1983-2011) including Klingenbrunn Bhf. and Großer Arber weather station. Fills indicate significant trends $(\mathrm{p}<0.05)$. 
In UV, die-off in Norway spruce was first recorded in 2003 and was found on $21 \%$ of the catchment area, $3.6 \%$ of which was salvage-logged. At this time, the extent of die-off in UV was clearly less than in UGO (39\%). By the time continuous monitoring began in 2006, the disturbed area had reached $25 \%$ of the catchment area. Dead trees were left on $14 \%$, and harvested on $11 \%$ of the catchment. The most severe bark beetle outbreak was recorded between 2008 and 2011, and followed severe windfall over large areas of the catchment caused by the storm Kyrill. By 2011 the disturbed area had reached 54\% of the catchment. Apart from these forest cover changes, no other changes in land cover occurred in the UGO and GO.

In summary, the percentage disturbed area in UV and UGO was similar, yet differed in the occurrence and extent of salvage logging and in the progression and timing of disturbances.

\section{Case study Upper Große Ohe catchment: runoff response to forest disturbance}

From 1980 to 2011, precipitation in UGO was constant as examined by trend analysis and breakpoint analysis (Fig. 7, right). Yet, the runoff coefficient varied between $52 \%$ and $76 \%$ (Fig. 7, left). There was a significant breakpoint $(\mathrm{p}<0.03)$ in the time series separating a first period (1980-1998) from a second period (1999-2011). Regression lines for both periods were horizontal. The mean values differed significantly $(p<0.003)$ between the before-breakpoint period $(59 \% \pm 5 \%)$ and the after-breakpoint period $(65 \% \pm 5 \%)$. After the breakpoint, mean precipitation and runoff was $52 \mathrm{~mm} \mathrm{y}^{-1}(3 \%, \mathrm{p}<0.29)$ and $123 \mathrm{~mm} \mathrm{y}^{-1}(13 \%, \mathrm{p}<0.06)$ higher than before (Fig. 7, right). Therefore, the mean catchment balance, which approximated the mean evapotranspiration in the longer term, was $72 \mathrm{~mm}$ lower $(11 \%, \mathrm{p}<0.02)$ than before. The breakpoint found coincided with about $30 \%$ of the cumulative area of Norway spruce stands recorded killed by bark beetle in the catchment area in 1999 (Fig. 6).

\section{Discussion}

On an annual time scale, runoff yield decreased slightly in GO $\left(-1.5 \mathrm{~mm} \mathrm{yr}^{-1}\right)$ and UV $\left(-1.0 \mathrm{~mm} \mathrm{yr}^{-1}\right)$ due to a decrease in summer runoff. This does not conflict with slightly increased precipitation yields during summer at most stations (Table 2), since significantly increased air temperatures (Fig. 5) probably have increased evapotranspiration. In UGO, however, annual runoff increased by $2.3 \mathrm{~mm} \mathrm{yr}^{-1}$, probably due to the large-scale Norway spruce die-off caused by bark beetle. Those trees killed lost all needles within the first few months followed by their twigs within a few years. This reduced to a minimum their interception and transpiration surface, and hence evapotranspiration from the stand (Anderegg et al., 2012), while enhancing the precipitation yields on the ground. For UV, the picture of decreasing runoff is contradictory given the large-scale change in land cover caused by storms and bark beetle (Fig. 6). Indeed, runoff in UGO increased, but not significantly, even though disturbances of similar size occurred much earlier.
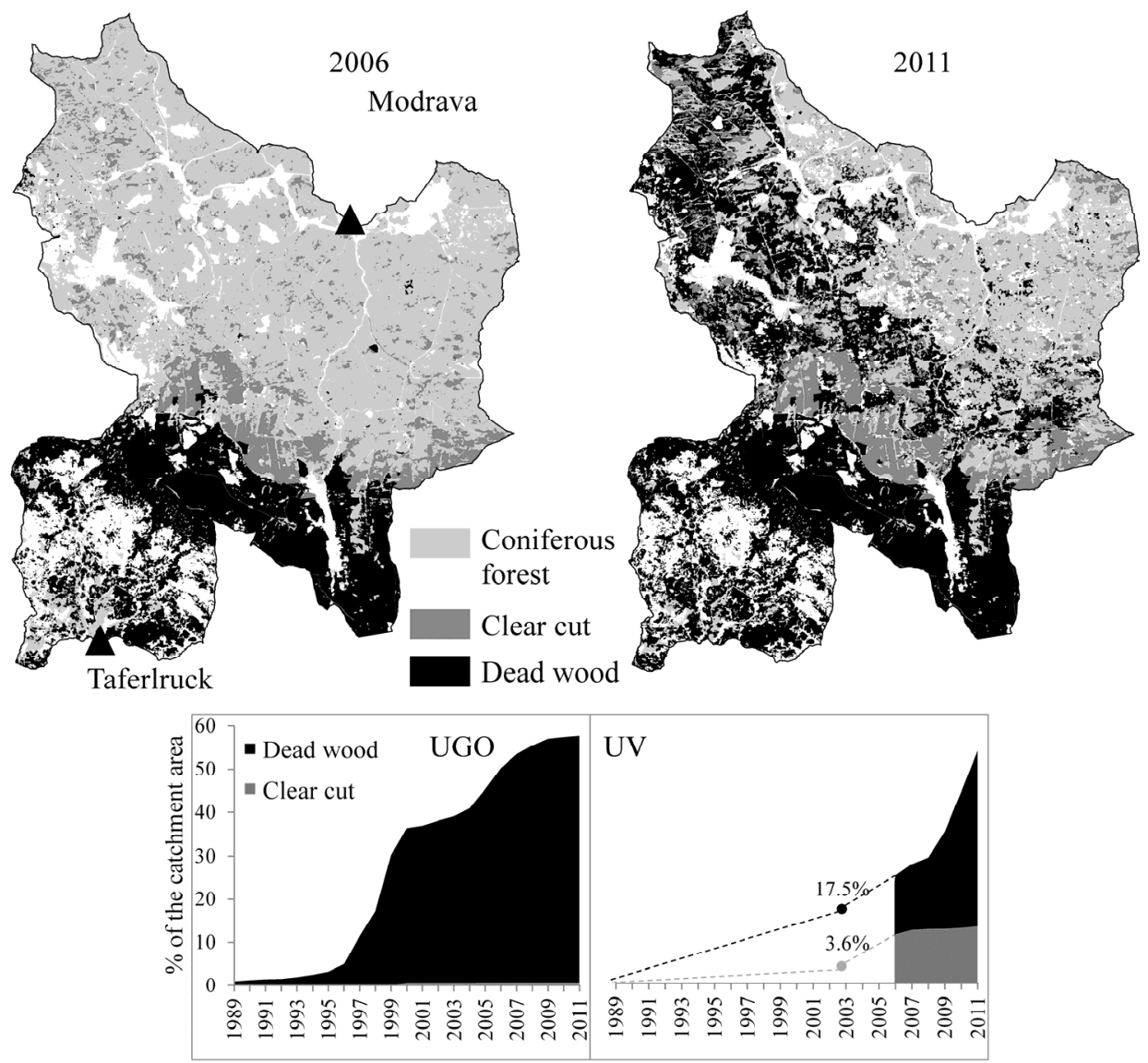

Fig. 6. Forest cover change due to bark beetle and wind disturbance in UGO (gauging station Taferlruck) and UV (gauging station Modrava). Top: Spatial distribution of disturbed Norway spruce stands in 2006 and 2011. Bottom: Cumulative curve of disturbed stands in $\%$ catchment area. Note that in UV records started in 2003. 


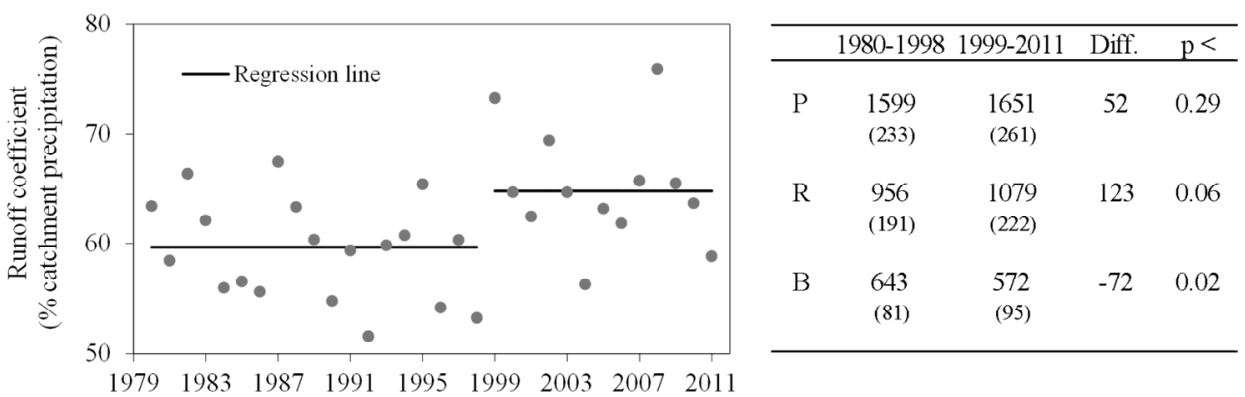

Fig. 7. Left: Anual runoff coefficient (\% catchment precipitation) in UGO. A significant breakpoint in 1998/1999 was detected by SegReg (Oosterbaan, 1994) and confirmed by independent procedures. Right: Mean values ( \pm standard deviation) of precipitation $\mathrm{P}$, runoff R and catchment balance $\mathrm{B}$ for the before and after breakpoint period and their differences $\left(\mathrm{mm} \mathrm{yr}^{-1}\right)$.

\section{Runoff response to forest disturbance}

For UGO, a breakpoint analysis of the runoff coefficient demonstrated that the hydrological cycle had altered significantly by 1999 when the loss of tree cover reached $30 \%$ of catchment area (Fig. 6). After this breakpoint, the mean runoff coefficient increased by $6 \%$ of catchment precipitation $(\mathrm{p}<0.003)$ and evapotranspiration was $72 \mathrm{~mm} \mathrm{yr}^{-1}$ lower $(11 \%$, $\mathrm{p}<0.02$ ) than before (Fig. 7). Two small nested headwater catchments in UGO experienced a larger rise in runoff ratio (Beudert et al. 2007) once loss of tree cover exceeded $25 \%$ of the catchment area. This suggests the damping of disturbance signals on a larger scale (Blöschl et al., 2007). In a review, Adams et al. (2012) hypothesized a significant decrease in catchment evapotranspiration once absolute canopy cover loss from die-off exceeded $20 \%$, and annual precipitation about 500 $\mathrm{mm}$. The persistence of decreased evapotranspiration in UGO until now might be due to the bimodal die-off dynamics (Fig. 6). In stands killed during the first die-off wave, dense and fastgrowing stand regeneration was increasingly able to compensate for diminished evapotranspiration losses due to mature tree mortality (Brown et al., 2014). Almost a decade later, this recovery was impacted by the second wave of die-off, which hampered a rapid comeback of catchment evapotranspiration to pre-disturbance level. Based on these findings and ignoring scale effects, disturbances may not have been rapid enough in $\mathrm{UGO}$, and too late in UV to generate significant trends in runoff yields up to now.

\section{High flow in late winter and early spring}

Annual flow measures did not change in UGO, whereas, in UV, low to medium flows (P10 to P60) decreased significantly (Fig. 3). High flows (P80, P90) increased in March in all catchments $(\mathrm{p}<0.05)$, and in April in UV only (Fig. 3).Relative high flows (P60-P90, Fig. 4) and runoff yields increased in all catchments in March. These hydrological changes were not caused by altered precipitation during winter, which decreased slightly (Table 2). In contrast, all flow measures decreased in May and June in all catchments (not significantly), while precipitation yields increased slightly (Table 2 ).

The more pronounced flow trends in UGO compared to small changes in GO direct the discussion to land cover changes which, compared to conditions of complete tree canopy, enhanced the energy and water yields on ground surface and understory. Norway spruce killed by bark beetle shed needles within one year after infestation and fine woody debris within a few years, causing decreases in leaf area and whole plant surface area. The loss of live trees caused changes in the interception and storage of snow in the tree canopy and its accumula- tion on ground (Boon, 2007; Redding et al., 2008). Since winter precipitation yields decreased slightly, (I) water storage in snow cover must increase, (II) snow melt must be more rapid or (III) have shifted - or more than one of the above simultaneously - to cause increased high flows in late winter and early spring.

(I) Compared to stands with undiminished canopy cover, snow retention on, and losses from stand surfaces via sublimation and wind drift are reduced, so that snowfall to the ground is higher and the water equivalent of snow cover also greater (Boon, 2007; Musselmann et al., 2008; Pugh and Gordon, 2012). During the first years after complete die-off, maximum snow water storage on Norway spruce plots in UGO increased by about $100 \mathrm{~mm}$ throughout the elevation range (Beudert, 2014, personal communication). Because snow accumulation on the ground is inversely related to canopy density (Gary and Troendle, 1982), enhanced snow storage persists during the snagfall period until the growth rate of understorey and young trees accelerates and closes canopy cover. Due to the spatial spread of dead Norway spruce stands over 15 years in UGO (Fig. 6), a mosaic of areas with different snow accumulation characteristics probably diminished the increasing effect of bark beetle infestations on mean catchment snow water equivalent. For GO, vegetation cover changes in UGO were too small (Table 1) to induce detectable hydrological responses. However, UV should be subject to increases in snow water storage due to accelerated vegetation cover changes since 2008 (Fig. 6). In addition, unmanaged disturbed stands accumulate much less snow than cleared stands (Boon, 2007; Redding et al., 2008), which comprise $11 \%$ of UV. This might partly explain the more pronounced high flow trends in March and April (Fig. 3).

(II) Compared to stands with undiminished canopy cover, transmission is largely increased in stands killed by bark beetle (Boon, 2009; Pugh and Small, 2012), thereby increasing the energy input for snow ablation. Ablation rates are reported to increase, whereas snow cover was one to two weeks longer due to greater snow accumulation (Molotch et al., 2009). Studies in British Columbia revealed only slightly higher ablation rates in dead stands compared to live stands (Boon, 2012), while snow storage equalled clear-cut areas, resulting in a lengthened snow cover period. Similarly, Pugh and Small (2012) found higher melting rates in fully defoliated stands compared to live stands in high elevation forests in Colorado and, depending on meteorological conditions, advanced snow depletion days as well. In each case study, presence, absence or the amount of needle, branch and bark litter covering the snow layer played an important role in melt dynamics by changing the surface albedo (Melloh et al., 2001; Winkler et al., 2010). The albedo effects last only a few years after infestation, for as long as needles and fine woody debris are shed from dead trees. This restricts marked hydrological consequences to a small number of post- 
infestation years provided that extended tree die-off occurred within a narrow time frame of a few years. During the snagfall period, snow cover albedo approximates open site conditions as long as the succeeding ground vegetation regrowth is minimal. Since the high flow trends in our study sites point to earlier rather than delayed ablation, bark beetle-induced land cover changes are very probably not responsible for altered hydrological conditions in GO. In UV, $11 \%$ of clear-cut area could play a special role as it combines higher snow yields and higher ablation rates by incoming radiation compared to unmanaged dead stands, resulting in an earlier removal of a thicker snowpack. However, areas with delayed ablation should override areas with opposite characteristics in UV, for which restoration effects on snow pack dynamics in peat bogs remain unresolved.

(III) Early spring warming was most pronounced in April $(\sim+4 \mathrm{~K})$ throughout the study region (Fig. 5), pointing to altered melting dynamics of snow. Indeed, by 2011, snow cover period ended significantly earlier by at least 25 days than in 1978 (Fig. 8). The end of snow melt ranged from the beginning/middle of May to the beginning/middle of April depending on altitude. Consequently, water in snow pack was mobilized more than three weeks earlier, causing increases in runoff yields, while high flows remained constant (Fig. 3). In UGO, this resulted in significant negative trends in relative high flows in April (Fig. 4) since most snow had already melted by the end of March in most years.

In UV however, snow melt and runoff response continued until April, probably because the mean altitude (1134 m a.s.l) was higher than GO and UGO. Despite equal warming trends (Fig. 5), lower air temperatures and more frequent negative night-time temperatures retard snow melt. Nevertheless, decreased high flows and increased relative high flows in May arising from reduced runoff yields prove that most of snow water in UV was lost by the end of April.

Assuming that the beginning of the snow cover period, the maximum snow water equivalents and the onset of springtime snowmelt did not change significantly, this shift in final snow melt alone implies a more intensified activation of water (Mollini et al., 2011). However, it can be assumed that temperature increases in February of 0.5 to $0.7 \mathrm{~K} \mathrm{yr}^{-1}$ (Fig. 5), albeit not significant, exerted an initial overall mobilizing effect on snowpack, resulting in increasing absolute and relative high flows in March (and April in UV).

Earlier snow melt and increased late winter/early spring runoff have been reported for streams dominated or markedly influenced by snow across the northern hemisphere, i.e. in western United States (Maurer et al., 2007; McCabe and Clark, 2005; Stewart et al., 2005), Scandinavia (Hisdal et al., 2010) and Central Europe (Fiala et al 2010; Renner and Bernhofer,
2011; Stahl et al., 2010). At present, of the hemispheric climate change effects in the most accepted scenarios (IPCC 2013), late winter and early spring warming is hydrologically much more important than increasing precipitation. Direct and indirect effects of land cover change by bark beetle, storm and restoration on snowpack dynamics seem to be in balance and have a minor impact on flooding during winter.

\section{Low flow in summertime}

Negative trends have been reported for low flows in summer and autumn in some parts of the northern hemisphere (Birsan et al., 2005; Chang et al., 2012; Stahl et al., 2010). Yet opposite trends are evident as well in Great Britain (Dixon et al., 2006) and Northern Scandinavia (Wilson et al., 2010), for example, where precipitation in summer has increased.

In the study catchments (Fig. 4), there was no significant decrease in relative low flows in any of the summer months. Small absolute decreases in low flows in May were caused by earlier snow melt and do not reflect drier weather conditions. This is in line with slightly increased precipitation yields in summer at all stations (Table 2). However, air temperatures increased markedly, and mostly significantly, in all months from May to August (Fig. 5), enhancing potential evapotranspiration. Nevertheless, relative low flows increased significantly in September and October (GO) and in August (UGO). This may be related to the tree cover loss since evapotranspiration is the most important biophysical process affected negatively by tree die-off (Anderegg et al., 2012). As winter precipitation yields did not decrease, groundwater control on low flows in summer did not change. The widespread die-off of mature Norway spruce stands, however, markedly reduced the transpiration demand and diminished the overall water loss from above-ground surfaces. Consequently, during summer, increased seepage water fluxes and groundwater recharge enabled unaltered, or even higher low flows (Bearup et al., 2014).

\section{CONCLUSIONS}

In forested landscapes, climate change can exert various direct (esp. precipitation, temperature) and indirect effects (favouring pests, impairing trees), virtually all of which have an impact on the hydrological cycle. In the Bohemian Forest, and in both national parks especially, extended forest cover changes by storm and bark beetle outbreaks over the last 25 years should have altered runoff generation processes and yields by diminishing evapotranspiration and changing snow cover dynamics, thereby confounding direct climate change effects.

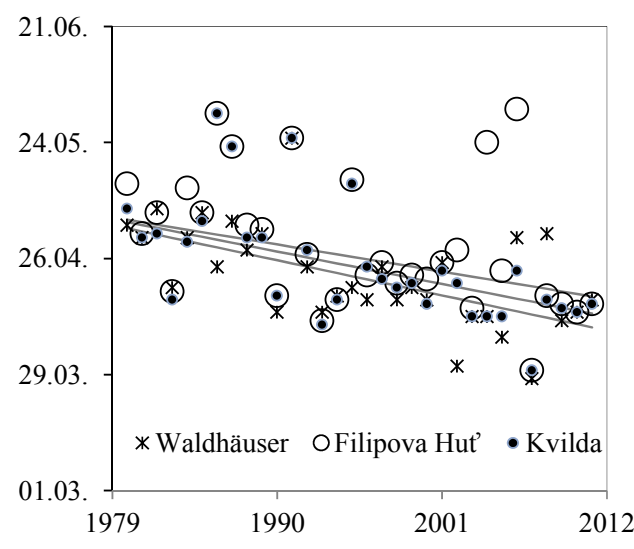

\begin{tabular}{cccc}
\hline & $\begin{array}{c}\text { Wald- } \\
\text { häuser }\end{array}$ & Kvilda & $\begin{array}{c}\text { Filipova } \\
\text { Hut' }\end{array}$ \\
\hline m a.s.1. & 940 & 1052 & 1112 \\
days & -24 & -25 & -25 \\
d yr $^{-1}$ & -0.8 & -0.8 & -0.8 \\
p $\leq$ & 0.001 & 0.001 & 0.01 \\
\hline
\end{tabular}

Fig. 8. Trend in the last day of the snow cover at Waldhäuser, Filipova Hut' and Kvilda weather station. 
The hydrological analysis of the three catchments in the Bohemian Forest revealed small changes in precipitation and small changes in annual runoff yields in UV $(-3 \%)$, GO $(-8 \%)$ and UGO $(+8 \%)$. In UGO, mean catchment balance decreased significantly by $72 \mathrm{~mm} \mathrm{yr}^{-1}(11 \%)$ when the loss of tree cover reached $30 \%$ of catchment area. In addition, low flow measures significantly increased in August (UGO) and September (GO), while runoff yields did not change. This underpins the importance of diminished evapotranspiration from severely disturbed stands, which enable increased groundwater recharge during summer. The public and private drinking water supply, an important ecosystem service, currently benefits from largescale disturbances, especially in autumn, as long as stand regeneration is likely to consume less water than a mature stand. However, how long hydrological disturbance effects will persist still needs to be clarified (Adams et al., 2012) and should be the subject of future regional investigations.

In contrast, the overall warming in February $\left(+1.8^{\circ} \mathrm{C}\right)$ and April $\left(+4^{\circ} \mathrm{C}\right)$ accelerated snow melt and significantly increased runoff and high flows in March in all catchments irrespective of size, land cover or land cover changes. Moreover, other changes in high flows could not be found even in the severely affected catchments UV and UGO.

Thus, given the results of this study and scientific information from comparable landscapes, an assignment of intensified high flows to forest disturbance or to neglecting salvage logging measures was not found. Nevertheless, further research on increasing winter precipitation, which IPCC (2013) predicts, is required, as it may accelerate the ongoing temperature-driven increases in winter high flows and aggravate the flooding risks at larger scales in lowlands.

Acknowledgements. We thank the Bavarian Forest and Sumava National Park authorities as well as the German Weather Service (DWD), Bavarian State Institute of Forestry (LWF) and the Czech Hydrometeorological Institute (CHMI) for providing meteorological data. We are thankful to the Czech Hydrometeorological Institute (CHMI) and the Bavarian Environment Institute (LFU) for the provision of runoff records. The research was supported by the Czech Science Foundation project P209/12/0997.

\section{REFERENCES}

Adams, H.D., Guardiola-Claramonte, M., Barron-Gafford, G.A., Villegas, J.C., Breshears, D.D., Zou, C.B., et al., 2009. Temperature sensitivity of drought-induced tree mortality portends increased regional die-off under global-change-type drought. Proceedings of the National Academy of Sciences, 106, 7063-7066.

Adams, H.D., Luce, C.H., Breshears, D.D., Allen, C.D., Weiler, M., Hale, V.C., et al., 2012. Ecohydrological consequences of drought-and infestation-triggered tree die-off: insights and hypotheses. Ecohydrology, 5, 145-159.

Allen, C.D., Macalady, A.K., Chenchouni, H., Bachelet, D., McDowell, N., Vennetier, M., et al., 2010. A global overview of drought and heat-induced tree mortality reveals emerging climate change risks for forests. Forest Ecology and Management, 259, 660-684.

Anderegg, W.R.L., Kane, J.M., Anderegg, L.D.L., 2012. Consequences of widespread tree mortality triggered by drought and temperature stress. Nature Climate Change, 3, 30-36.

Archer, D.R., Newson, M., 2002. The use of indices of flow variability in assessing the hydrological and instream habitat impacts of upland afforestation and drainage. Journal of Hydrology, 268, 244-258.

Bässler, C., 2008. Climate change - trend of air temperature in the Innerer Bayerischer Wald (Bohemian Forest). Silva Gabreta, 14, 1-18.

Bässler, C., Müller, J., Hothorn, T., Kneib, T., Badeck, F., Dziock, F., 2010. Estimation of the extinction risk for highmontane species as a consequence of global warming and assessment of their suitability as cross-taxon indicators. Ecological Indicators, 10, 341-352.

Bearup, L.A., Maxwell, R.M., Clow, D.W., McCray, J.E., 2014. Hydrological effects of forest transpiration loss in bark beetle-impacted watersheds. Nature Climate Change, 4, 481-486.

Beudert, B. Breit, W., 2004. Zwölf Jahre IntegratedMonitoring-Programm an der Meßstelle Forellenbach im Nationalpark Bayerischer Wald. [Twelve years of the integrated-Monitoring-Program at the Forellenbach monitoring station in Bavarian Forest National Park]. Nationalparkverwaltung Bayerischer Wald, Grafenau. (In German.)

Beudert, B., Klöcking, B., Schwarze, R., 2007. Große Ohe. Impact of bark beetle infestation on the water and matter budget of a forested catchment. In: Puhlmann, H. Schwarze, R. (Eds): Forest hydrology - results of research in Germany and Russia. Deutsches Nationalkomitee für das International Hydrological Programme (IHP) der UNESCO und das Hydrology and Water Resources Programme (HWRP) der WMO. IHP/HWRP-Berichte Heft 6, Koblenz.

Birsan, M.V., Molnar, P., Burlando, P., Pfaundler, M., 2005. Streamflow trends in Switzerland. Journal of Hydrology, 314, 312-329.

Blöschl, G., Ardoin-Bardin, S., Bonell, M., Dorninger, M., Szolgay, J., 2007. At what scales do climate variability and land cover change impact on flooding and low flows? Hydrological Processes, 21, 1241-1247.

Boon, S., 2007. Snow accumulation and ablation in a beetlekilled pine stand in Northern Interior British Columbia. BC Journal of Ecosystems and Management, 8, 1-13.

Boon, S., 2009. Snow ablation energy balance in a dead forest stand. Hydrol. Process., 23, 2600-2610.

Boon, S., 2012. Snow accumulation following forest disturbance. Ecohydrology, 5, 279-285.

Brown, M.G., Black, T.A., Nesic, Z., Foord, V.N., Spittlehouse, D.L., Fredeen, A.L., Meyer, G., 2014. Evapotranspiration and canopy characteristics of two lodgepole pine stands following mountain pine beetle attack. Hydrol. Process., 28, 3326-3340.

Buchtele, J., Buchtelová, M., Tesař, M., 2006. Role of vegetation in the variability of water regimes in the Šumava Mts forest. Biologia, 61, Suppl. 19, S246-S250.

Chang, H., Jung, I.W., Steele, M., Gannett, M., 2012. Spatial patterns of March and September streamflow trends in Pacific Northwest streams, 1958-2008. Geographical Analysis, 44, 177-201.

Dixon, H., Lawler, D.M., Shamseldin, A.Y., 2006. Streamflow trends in western Britain. Geophysical Research Letters, 33, 19, L19406.

Fiala, T., Ouarda, T.B., Hladný, J., 2010. Evolution of low flows in the Czech Republic. Journal of Hydrology, 393, 206-218.

Gary, H.L, Troendle, C.A., 1982. Snow accumulation and melt under various stand densities in Lodgepole pine in Wyoming and Colorado. USDA Forest Service. Rocky Mountain Forest and Range Experiment Station, Fort Collins. 
Gilbert, R.O., 1987. Statistical methods for environmental pollution monitoring. Van Nostrand Reinhold, New York.

Hais, M., Jonášová, C., Langhammer, J., Kučera, T., 2009. Comparison of two types of forest disturbance using multitemporal Landsat TM/ETM+ imagery and field vegetation data. Remote Sensing of Environment, 113, 835-845.

Hidalgo, H.G., Das, T., Dettinger, M.D., Cayan, D.R., Pierce, D.W., Barnett, T.P. et al., 2009. Detection and attribution of streamflow timing changes to climate change in the Western United States. Journal of Climate, 22, 3838-3855.

Hirsch, R.M., Slack, J.R. Smith, R.A., 1982. Techniques of trend analysis for monthly water quality data. Water Resources Research, 18, 107-121.

Hisdal, H., Holmqvist, E., Jonsdottir, J.F., Jonsson, P., Kuusisto, E., Lindstrom, G., Roald, L.A., 2010. Has streamflow changed in the Nordic countries? NVE Report No. 1, Oslo.

IPCC 2013. Climate Change 2013. The Physical Science Basis. In: Stocker, T.F., Qin, D., Plattner, G.-K., Tignor, M., Allen, S.K., Boschung, J., Nauels, A., Xia, Y., Bex, V., Midgley, P.M. (Eds.): Contribution of Working Group I to the Fifth Assessment Report of the Intergovernmental Panel on Climate Change. Cambridge University Press, Cambridge, New York.

Kliment, Z., Matouskova, M., 2008. Long-term trends of rainfall and runoff regime in Upper Otava river basin. Soil Water Res., 3, 155-167.

Klöcking, B., Schwarze, R., Beudert, B., Suckow, F., Lasch, P., Badeck, F., Pfützner, B., 2005. Auswirkungen des Borkenkäferbefalls auf den Wasser- und Stoffhaushalt zweier Gewässereinzugsgebiete im Nationalpark Bayerischer Wald. Schriftenreihe Wasserhaushalt und Stoffbilanzen im naturnahen Einzugsgebiet Große Ohe. [Influence of the barkbeetle outbreak ont he water and mass balance in two catchments in Bavarian Forest National Park]. Nationalparkverwaltung Bayerischer Wald, Grafenau. (In German.)

Määttä, A., Salmi, T., Anttila, P., Ruoho-Airola, T., 2002. MAKESENS 1.0. EXCEL template for the calculation of trend statistics of annual time series. Finnish Meteorological Institute, Helsinki.

Marvel, K., Bonfils, C., 2013. Identifying external influences on global precipitation. Proceedings of the National Academy of Sciences, 110, 19301-19306.

Maurer, E.P., Stewart, T., Bonfils, C., Duffy, P.B., Cayan, D., 2007. Detection, attribution, and sensitivity of trends toward earlier streamflow in the Sierra Nevad. Journal of Geophysical Research, 112, D11118.

McCabe, G.J., Clark, M.P., 2005. Trends and variability in snowmelt runoff in the western United States. Journal of Hydrometeorology, 6, 476-482.

Melloh, R., Hardy, J., Davis, R. Robinson, P., 2001. Spectral albedo/reflectance of littered forest snow during the melt season. Hydrological Processes, 15, 3409-3422.

Mollini, A., Katul, G.G., Porporato, A., 2011. Maximum discharge from snowmelt in a changing climate. Geophysical research Letters, 38, L05402.

Molotch, N.P., Brooks, P.D., Burns, S.P., Litvak, M., Monson, R.K., McConnell, J.R., Musselman, K., 2009. Ecohydrological controls on snowmelt partitioning in mixed-conifer subalpine forests. Ecohydrology, 2, 129-142.

Musselman, K., Molotch, N.P., Brooks, P.D., 2008. Quantifying the effects of forest vegetation on snow accumulation, ablation and potential meltwater inputs, Valles Caldera National Preserve, NM, USA. Hydrological Processes, 22, 2767-2776.
Oosterbaan, R.J., 1994. Agricultural drainage criteria. In: Ritzema, H.P. (Ed.): Drainage Principles and Applications. ILRI Publ. 16, Wageningen, The Netherlands, pp. 635-688.

Polson, D., Hegerl, G.C., Allan, R.P., Sarojini, B.B., 2013. Have greenhouse gases intensified the contrast between wet and dry regions? Geophysical Research Letters, 40, 4783-4787.

Project team ECA\&D, 2013. European Climate Assessment \& Dataset (ECA\&D), Algorithm Theoretical Basis Document (ATBD). Royal Netherlands Meteorological Institute KNMI, www.ecad.eu/documents/atbd.pdf

Pugh, E., Gordon, E., 2012. A conceptual model of water yield effects from beetle-induced tree death in snow-dominated lodgepole pine forests. Hydrol. Process., 27, 14, 2048-2060.

Pugh, E., Small, E., 2012. The impact of pine beetle infestation on snow accumulation and melt in the headwaters of the Colorado River. Ecohydrology, 5, 467-477.

Raffa, K.F., Aukema, B.H., Bentz, B.J., Carroll, A.L., Hicke, J.A., Turner, M.G., Romme, W.H., 2008. Cross-scale drivers of natural disturbances prone to anthropogenic amplification: The dynamics of bark beetle eruptions. Bioscience, 58, 501-517.

Redding, T., Winkler, R., Teti, P., Spittlehouse, D., Boon, S., Chatwin, S., 2008. Mountain pine beetle and watershed hydrology. In Mountain Pine Beetle. From Lessons Learned to Community-based Solutions Conference Proceedings, June 10-11, 2008. BC Journal of Ecosystems and Management, 9, 33-50.

Renner, M., Bernhofer, C., 2011. Long term variability of the annual hydrological regime and sensitivity to temperature phase shifts in Saxony/Germany. Hydrology and Earth System Sciences, 15, 1819-1833.

Seidl, R., Schelhass, M.J., Lexer, M.J., 2011. Unraveling the drivers of intensifying forest disturbance regimes in Europe. Global Change Biology, 17, 2842-2852.

Snedecor, G.W., Cochran, W.G., 1980. Statistical Methods. 7th ed. Iowa State University Press, Ames, Iowa, pp. 401-403.

Stahl, K., Hisdal, H., Hannaford, J., Tallaksen, L.M., van Lanen, H.A.J., Jodar, J., 2010. Streamflow trends in Europe. Evidence from a dataset of near-natural catchments. Hydrol. Earth Syst. Sci. Discuss., 7, 5769-5804.

Stepánek, R., 2008. AnClim - software for time series analysis. Dept. of Geography, Faculty of Sciences, Masaryk University Brno, http://www.climahom.eu.

Stewart, I.T., Cayan, D.R., Dettinger, M.D., 2005. Changes toward earlier streamflow timing across western North America. Journal of Climate, 18, 1136-1155.

Wessa, P., 2014. Paired and Unpaired Two Samples Tests about the Mean (v1.0.5) in Free Statistics Software (v1.1.23r7), Office for Research Development and Education, URL http://www.wessa.net/rwasp_twosampletests_mean.wasp/

Wilson, D., Hisdal, H., Lawrence, D., 2010. Has streamflow changed in the Nordic countries? - Recent trends and comparisons to hydrological projections. Journal of Hydrology, 394, 334-346.

Winkler, R., Boon, S., Zimonick, B., Baleshta, K., 2010. Assessing the effects of post-pine beetle forest litter on snow albedo. Hydrological Processes, 24, 803-812.

Received 8 December 2014 Accepted 18 June 2015 